\title{
HATE SPEECH ENDORSED BY RUSSIA'S INSTITUTE OF ETHNOLOGY
}

\author{
(An Open Letter from Russian Anthropologists to their Colleagues Abroad)
}

Moscow, 14 April 1995

Dear Colleagues:

We find it urgent to share with the world community of social scientists our anxiety and indignation about some dangerous trends in Russian anthropology.

Recent years have seen the emergence in Russia of various organized political groupings of neo-Nazi, White-supremacist, and/or extreme right-wing nationalistic orientation. One such group in the city of St Petersburg is called "Venedian Union." It is a neo-Paganist and extremely racist organization established and led by Viktor Bezverkhy, a former Professor of Marxism in one of the city colleges. In 1991, he was indicted for republishing and disseminating Hitler's Mein Kampf with "biased" commentaries. Investigation revealed that Bezverkhy was a leader of a racist group, and that he and his friends wrote an oath with their own blood to fight the Jews as "the worst enemies of mankind" and to oppose Christianity as a form of "international Jewish conspiracy against humanity." Bezverkhy was acquitted, however, since he claimed in court that he had only republished Mein Kampf for commercial profit.

In 1994, the St Petersburg Prosecutor's Office again indicted Bezverkhy for "inciting ethnic and racial hatred," this time in his own writings. One of these is titled Anthropology (1992), the other The Volkhvs [Ancient Slavic pagan priests]Philosophy of History (1993). Both books quite explicitly illustrate racial intolerance, vicious antisemitism, and open bigotry confessed by the author. Permit us to provide but a few quotations:

The course of history during many centuries has demonstrated that black-white bastards (i.e., Kikes, Gypsies, Mulattoes, and Quadroons) are absolutely needless in a socially organized society (i.e., among representatives of the species Homo) since they are completely incapable of being socially honest and have a low level of natural morality and thus are unable to become citizens of the Society. (Anthropology, p. 36)

The emergence of the Theory of Evolution in the nineteenth century highlighted the proper role of Kikes as human slag (i.e., waste). (Anthropology, p. 4)

Cultures created by White people are assimilated by the Yellow people, degraded by the Black people and destroyed by bastards. (Volkhvs, p. 3)

In the 1930s the Germans could unmistakably determine who is a Kike. This experience is worth study. (Anthropology, p. 41) 
In processing the case, the Prosecutor's Office requested the expert opinion of the most authoritative anthropological research body in Russia, the Moscow-based Institute of Ethnology and Anthropology of the Russian Academy of Sciences (the former Institute of Ethnography). The Institute duly supplied a fifteen-page expert opinion of Bezverkhy's writings and a few other similar publications, produced by Professor Viktor I. Kozlov and Senior Researcher Dr. Nadezhda Lebedeva, who were commissioned for this by the Director of the Institute.

The Prosecutor's Office had asked whether Bezverkhy's writings contained statements aimed, explicitly or implicitly, at inciting ethnic or racial hostility or hatred; insulted and humiliated "national honor and dignity"; was propaganda of superiority or inferiority of certain peoples; or restricted civil rights on ethnic or racial grounds. The experts' response to all these conditions was unequivocally negative, and was accompanied by a short remark worthy of mention:

In the Journal No. 3 (6), 1992, p. 36 [see, the first quotation from Bezverkhy's Anthropology] we found a negative statement about the Gypsies. But we don't precisely know what the meaning of Gypsies' 'national honor and dignity' is.

As such, the experts found nothing offensive when people are publicly named "black-white bastards" or Kikes or when they are declared "needless" in society or incapable of becoming citizens due to their low level of morality. In fact, some of the phrases of the experts' opinion are hardly distinguishable from Bezverkhy's own language:

As for the term "human slag (...waste)," it is indeed rude and groundless. But shouldn't the Judaists who elevate themselves over the "goyim," as over "second-class people," be psychologically aware that they will be humiliated in response.

They also hasten to add,

As is widely known, Jews-Judaists and Gypsies do indeed communicate within their own communities differently from the way they treat outsiders.

Following the expert opinion submitted by the respectable Institute of Ethnology the court again acquitted Bezverkhy in early 1995. This acquittal and the Institute's role was brought to public attention by several Russian newspapers (for example, Izvestiia 1995, n. 11, Moskovskie Novosti 1995, n. 5, etc.) and non-governmental organizations. A group of scholars sent a letter to the President of the Russian Academy of Sciences stating: "Never has Russian science been so humiliated-neither during the "Beylis case" [a notorious blood-libel case in Kiev in 1913], nor during Stalin's campaign against "rootless cosmopolitans." On 25 January 1995, the City Prosecutor of St. Petersburg appealed the lower court's decision.

Regrettably, the reaction of the Institute of Ethnology and Anthropology was quite different. The Institute's leadership did its best to avoid any public discussion of the expert opinion submitted by two of its members. In a short letter published in the newspaper Izvestiia (22 February 1995), the Institute's Director, Dr Valerii Tishkov, 
simply referred to this opinion as a "personal view of certain scholars," without expressing any of his own or his staff's attitude toward it. In fact, the majority of the Institute staff implicitly or quite explicitly approved the experts' position by compiling letters of support to Viktor Kozlov and by re-electing him with an overwhelming majority of votes to the Institute's Academic Board. That happened on 24 January 1995 , that is, after the acquittal of Bezverkhy and despite the highly negative publicity of the Institute's role in the case. When a few people tried to raise the issue of Kozlov's activities in condoning the Russian neo-Nazis and hate-groups, they were silenced by other fellow colleagues, outvoted, and marginalized.

In March 1995, there was another trial in Moscow. Another Russian fascist was indicted for publishing and disseminating "Catechism of the Soviet Jews," "The Protocols of the Elders of Zion" and similar antisemitic and racist forgeries. Not surprisingly, the court again relied upon a "well-known expert" in such cases, Professor Viktor Kozlov from the Institute of Ethnology, who again proved the "chauvinistic" nature of Judaism and clannishness of the Gypsies.

That is why, with much pain and bitterness, we have decided to send this letter informing our anthropologist colleagues about our current disgrace and shame. We believe that the indifference and connivance expressed by the Russian community of anthropologists towards racial hatred and ethnic bigotry has gradually transformed its main academic body, the Institute of Ethnology, into an established defender of Russian Neo-Nazis. We hope that joint efforts in condemning the Institute's position may save the honor of Russian Anthropology and will help us to throw racism, xenophobia and antisemitism off our academic grounds and out of our professional life.

Signatures [in alphabetic order]:

O. Artyomova
A. Borodatova
L. Perepyolkin
M. Chlenov
A. Pershitz
I. Kozhanovskaya
L. Sheinbaum
A. Kozhanovsky
V. Stelmakh
N. Kulakova
K. Tertitzky 